\title{
Tradutor jornalista ou jornalista tradutor? A atividade tradutória enquanto representação cultural
}

Meta Elisabeth Zipser Michelle de Abreu Aio

\section{Resumo}

O presente artigo visa apresentar a atividade tradutória dentro do campo jornalístico, estabelecendo a interface proposta por Zipser (2002) em que o jornalista passa a ser, acima de tudo, um tradutor de fatos. Pautando-se, por um lado, na proposta funcionalista de Nord (1991) para contemplar o conceito de tradução e, por outro, no modelo de Esser (1998), que organiza os fatores constitutivos do fazer jornalístico, pretendemos mostrar como uma reportagem é construida prospectivamente, ou seja, voltada para seu leitor a partir de um fato-fonte.

Palavras-chave: tradução; jornalismo; representação cultural; funcionalismo nordiano. 


\section{Introdução}

A interdisciplinaridade entre a tradução e o jornalismo já vem sendo tratada no campo dos Estudos da Tradução como objeto de análise e discussão sobre os possíveis diálogos entre as duas áreas (cf. ALMEIDA, 2005; POLCHLOPEK, 2005; SACHET, 2005; ZIPSER, 2002). Transportado para os domínios da prática jornalística, o conceito de tradução passa a pertencer não somente à esfera da transcriação de signos linguísticos, mas da intermediação cultural, acima de tudo. Se estendermos um pouco mais o alcance deste conceito, podemos considerar que o jornalista desempenha o papel de tradutor tendo o fato como texto-fonte que, depois de apurado, é traduzido para o público visado pela reportagem. Com vistas a este entrelaçamento entre as duas atividades é que pretendemos tecer, neste artigo, as bases do raciocínio que culminaram neste novo conceito, apresentado por Zipser (2002): do ato tradutório como representação cultural em textos jornalísticos.

\section{As contribuições do funcionalismo para os Estudos da Tradução}

As primeiras considerações funcionalistas no âmbito dos Estudos da Tradução surgem na Alemanha, nas décadas de 70 e 80, precisamente com a teórica e tradutora Katharina Reiss. Saindo de uma tradição em que as problemáticas da tradução giravam, sobretudo, em torno da equivalência, Reiss (1996) propõe que as funções que predominam no texto de partida devem ser consideradas como essenciais na avaliação da adequação do texto traduzido. A teórica desenvolve o que denomina de 'tipologia textual', também tida como situações comunicativas, e estabelece alguns fatores intra e extratextuais afim de nortear a tradução - fatores estes que serão expandidos posteriormente por Christiane Nord. Ainda que criticada por priorizar o textofonte, é mérito de Reiss a primeira consideração da importância do texto traduzido como algo mais do que repositório de signos linguísticos equivalentes. E Hans Vermeer (1986) quem fornece considerações adicionais à fundação da teoria funcionalista. Para ele, a tradução é uma ação humana que ocorre em busca de uma comunicação efetiva, funcional, implicando, portanto, em um propósito, uma intenção para o ato de comunicar. Vermeer faz uso da palavra grega skopos (objetivo, propósito) para definir sua teoria da ação proposital, em que o propósito da tradução é determinante dos fatores a serem considerados no ato tradutório. A tradução, portanto, deixa de ser um repositório estanque de transmissão do texto-fonte e passa a ser considerada como um processo em que elementos como o tipo de texto e o objetivo da tarefa tradutória são fundamentais para que o resultado final seja um texto adequado, funcional. 
Christiane Nord, tradutora e pesquisadora de tradução, aprimora o conceito de funcionalismo ampliando as propostas de Reiss e Vermeer, enfatizando a importância do receptor do texto no processo tradutório. Nord (1991) combina a tipologia textual de Reiss e o conceito de skopos de Vermeer para propor uma abordagem em que os elementos constitutivos do processo tradutório são constantemente revistos e a tradução adapta-se à função a que é atribuída.

\section{A proposta funcionalista de Christiane Nord}

Pautada em uma teoria com base na análise textual, Nord (1991) traz uma abordagem prospectiva da tradução, em que se voltam os olhos para o receptor da mensagem fazendo com que o texto-fonte seja adequado para a cultura de chegada a fim de cumprir a função a ele atribuída. Tal função é determinada, segundo Nord, para além do simples exame do texto-fonte. A autora afirma que "A função do texto-alvo não chega automaticamente de uma análise do texto-fonte, mas é definida pragmaticamente pelo propósito da comunicação intercultural." (NORD, 1991, p. 9, trad. nossa).

Assim considerada, a tradução de um texto será emoldurada culturalmente tanto pela função a ela atribuída quanto pela língua para a qual é feita. Sabendo que a língua é um dos maiores expoentes culturais, e sendo ela matéria-prima da atividade tradutória, o fator cultural torna-se indissociável da tradução. Por isso tanto o conhecimento da língua quanto da cultura estrangeira são essenciais dentre as competências tradutórias (cf. GONÇALVES; MACHADO, 2006) para que o tradutor possa depreender os elementos culturais do texto-fonte e enquadrá-los na cultura-alvo. Sobre esta questão, Nord (1991, p. 11, trad. nossa) afirma que

O domínio da cultura-fonte [pelo tradutor] deve permitir-lhe reconstruir as possíveis reações em um receptor do texto-fonte [...], enquanto o domínio da cultura de chegada lhe permite antecipar as possíveis reações de um receptor do texto traduzido, e então verificar a adequação funcional da tradução que produz.

Ao conhecer a cultura-fonte e a cultura-alvo o tradutor habilita-se a transitar entre texto-fonte e alvo com mais segurança, permitindo-lhe alcançar resultados mais satisfatórios no que toca à adequação cultural, visto que poderá reconhecer os traços mais sutis característicos de uma cultura ou de outra. No texto, a língua, por si só, traz os elementos que ajudam na identificação das marcas culturais. Na linguagem, segundo Bornstein (2001, p. 20, trad. nossa), seja ela de qualquer tipo,

[...] há todo um repertório de elementos, associações, conotações, insinuações, intenções e desejos que os acompanham [as 
palavras, ou signos, ou gestos], há um horizonte de referência que dá 'sentido' e impregna a mensagem.

Como em toda atividade comunicativa (e aqui incluímos o jornalismo), a tradução consuma-se no ato de sua leitura. Uma tradução que não é lida, ou consumida pelo leitor, não fechou o ciclo da situação comunicativa, que, no caso da tradução, começa pelo iniciador, que é aquele que encomenda a tradução de um texto já escrito, passa pelo tradutor, e tem como objetivo final alcançar o leitor (NORD, 1991). Portanto,

Como produto da intenção do autor, o texto permanece provisório até que seja recebido pelo receptor. É a recepção que completa a situação comunicativa e define a função do texto: o texto enquanto ato comunicativo é 'concluído' pelo receptor. (Idem, p. 16, trad. nossa).

O estabelecimento da função da tradução, no início do ciclo comunicativo, passa a ser o ponto chave para a re-textualização do texto-fonte. Tendo em conta que um mesmo texto-fonte pode resultar em diferentes traduções dependendo de diversos fatores - tais como propósito da tradução, cultura de chegada, época da recepção do texto, tipo de receptor, etc. - podemos dizer que um texto-fonte pode resultar em diferentes textos-alvo dependendo das funções que a ele podemos atribuir. Da mesma maneira, na atividade jornalística, podemos considerar que um único fato noticioso pode resultar em reportagens distintas de acordo com o contexto em que será publicado. Mesmo dentro da cultura brasileira, um único fato gera diferentes reportagens nas diversas revistas que circulam no país. No caso do jornalismo, o principal elemento que influencia qual enfoque a ser priorizado na reportagem - visto que a função inerente do texto jornalístico é informar - é o tipo de receptor do texto. O mesmo argumento pode ser usado para justificar as diferentes traduções obtidas de um único texto-fonte.

Embora sob a perspectiva funcionalista haja uma maior valorização do contexto de recepção da tradução, ela não é vista como uma atividade realizada de forma inadvertida, perdendose qualquer relação com o texto de origem. Pelo contrário: Nord considera a tradução como a produção de um texto funcional que mantém uma relação com o texto-fonte de acordo com a função que se pretende dar ao texto-alvo: "A tradução é a produção de um texto-alvo funcional que mantém uma relação com um dado texto-fonte, especificado de acordo com a função pretendida ou solicitada do texto-alvo." (NORD, 1991, p. 28, trad. nossa). Ou seja, embora a função estabelecida para o texto-alvo seja diferente da primeira função do texto-fonte, os textos continuam tendo uma relação entre si. Não se trata de uma tradução livre de amarras, mas de uma adequação do texto original aos interesses de quem 
encomenda a tradução - ou seja, a função atribuída a determinado texto-fonte no transporte para uma cultura-alvo.

Para Nord, existem alguns fatores que, uma vez identificados, permitem uma melhor visualização e atribuição da função do texto-fonte - especialmente quando ela não é explícita pelo iniciador da tradução. Estes fatores são chamados por Nord de intra e extra-textuais. Para uma melhor visualização destes elementos, apresentamos a seguir o modelo de Nord em português extraído do trabalho de Zipser (2002, p. 54), em que se apresentam os fatores intra e extra-textuais (traduzidos para o português) em forma de tabela (Tab. 1). Sendo um modelo bastante didático, ele pretende servir de norteador para o acesso à função do textofonte e do texto alvo, além de auxiliar nas escolhas tradutórias e na solução de dúvidas que por vezes surgem no decorrer do processo.

Tabela 1 - Modelo funcionalista nordiano

\begin{tabular}{|c|c|c|c|}
\hline \multicolumn{4}{|l|}{$\begin{array}{l}\text { TEXTO FONTE } \\
\text { TEXTO META }\end{array}$} \\
\hline & $\begin{array}{l}\text { TEXTO- } \\
\text {-FONTE }\end{array}$ & $\begin{array}{l}\text { QUESTÕES DE } \\
\text { TRADUÇÃO }\end{array}$ & TEXTO-ALVO \\
\hline \multicolumn{4}{|c|}{ FATORES EXTERNOS AO TEXTO } \\
\hline \multicolumn{4}{|l|}{ Emissor } \\
\hline \multicolumn{4}{|l|}{ Intenção } \\
\hline \multicolumn{4}{|l|}{ Receptor } \\
\hline \multicolumn{4}{|l|}{ Meio } \\
\hline \multicolumn{4}{|l|}{ Lugar } \\
\hline \multicolumn{4}{|l|}{ Tempo } \\
\hline \multicolumn{4}{|l|}{ Propósito (motivo) } \\
\hline \multicolumn{4}{|l|}{ Função textual } \\
\hline \multicolumn{4}{|c|}{ FATORES INTERNOS AO TEXTO } \\
\hline \multicolumn{4}{|l|}{ Tema } \\
\hline \multicolumn{4}{|l|}{ Conteúdo } \\
\hline \multicolumn{4}{|l|}{ Pressuposições } \\
\hline \multicolumn{4}{|l|}{ Estruturação } \\
\hline \multicolumn{4}{|l|}{$\begin{array}{l}\text { Elementos não- } \\
\text {-verbais }\end{array}$} \\
\hline \multirow{2}{*}{\multicolumn{4}{|c|}{$\begin{array}{l}\text { Léxico } \\
\text { Sintaxe }\end{array}$}} \\
\hline \multirow{2}{*}{\multicolumn{4}{|c|}{$\begin{array}{l}\text { Sintaxe } \\
\text { Elementos supra- } \\
\text { segmentais }\end{array}$}} \\
\hline & & & \\
\hline Efeito do texto & & & \\
\hline
\end{tabular}

Como o receptor é considerado o elemento mais importante na abordagem prospectiva de análise de texto voltada para a tradução, as informações sobre ele são de extrema importância 
- e elas podem ser extraídas do próprio texto, que, na tradução, carrega informações a serem inferidas sobre o receptor pretendido no texto-fonte e, numa reportagem, o tipo de público que se pretende alcançar. Com isso é possível presumir algumas características deste receptor: "[...] idade, gênero, formação, experiência social, origem geográfica, status social, papel em relação ao emissor, etc." (NORD, 1991, p. 5, trad. nossa). Por outro lado, as características do emissor podem ser inferidas pelo ambiente do texto, incluindo seu título, e outros como meio, lugar, tempo e motivo de sua publicação.

A identificação de todos, ou de alguns destes elementos no texto-fonte fornecem ao tradutor subsídios sobre os quais pode basear, e até justificar, suas escolhas tradutórias. Por analogia, do mesmo modo que é possível estabelecer os elementos a serem considerados na confecção do texto-alvo em uma tradução prospectiva, ou seja, voltada para o leitor do texto, podemos identificar os mesmos elementos no texto jornalístico, e com isso distinguir as características culturais presentes na reportagem. A identificação, em uma reportagem, dos fatores sugeridos por Nord pode fornecer subsídios para que se conheça o público a que se destina tal texto, e do efeito que se pretende causar com cada reportagem.

Tendo aqui discutido a importância do fator cultural presente em atividades cuja matéria-prima é a língua - em forma de texto - presume-se que seus profissionais possuam, além do conhecimento do(s) idioma(s) com o(s) qual(is) constroem textos, também do panorama cultural de sua produção. Sobre este aspecto, Gonçalves e Machado (2006, p. 59) afirmam:

Visto que o conhecimento cultural exerce grande influência no ato tradutório, seria ideal que tradutores em treinamento tivessem um profundo conhecimento sobre aspectos culturais tanto do seu país quanto do(s) país(es) da(s) língua(s) estrangeira(s) de trabalho, pois a percepção consciente dos aspectos culturais, inevitavelmente envolvidos na construção de um texto, serão decisivos no seu processo de retextualização na língua-alvo.

Os mesmos conhecimentos devem ser exigidos dos profissionais do jornalismo, responsáveis pela confecção de reportagens sempre voltadas a um mercado determinado, com suas características culturais específicas. A própria conscientização de que a reportagem configura-se como a tradução de um fato noticioso - admitindo-se, com isso, a possibilidade de haver várias outras reportagens sobre um mesmo fato redigidas de modos diversos de acordo com seus contextos culturais de recepção já se mostraria um grande passo rumo à discussão de questões como imparcialidade, veracidade, ética, etc. 


\section{Frank Esser e ofazer jornalístico constituído por instâncias}

Proveniente da área do jornalismo, a proposta do teórico alemão Frank Esser muito tem a colaborar com a interface inédita proposta por Zipser (2002), em que faz uma rica analogia com o funcionalismo de Christiane Nord. A partir dela criou-se uma nova ramificação para os Estudos da Tradução em que o ato tradutório é visto como representação cultural.

Além de apresentarem-se como atividades cujos resultados são culturalmente engendrados, ambas possuem o leitor como ponto final e têm origem em processos que são considerados uma situação comunicativa. Sendo o jornalismo uma atividade que tem como ponto de chegada o público específico ao qual se destina, e estando o jornalista inserido nesse mesmo espaço cultural, devemos levar em conta que o contexto histórico, cultural, econômico, jurídico, ideológico, etc. em que se encontra este público acabará por determinar o teor da reportagem.O teórico Frank Esser (1998) nos traz um novo olhar sobre os fatores que influenciam o fazer jornalístico. Segundo o próprio autor, "[...] a questão dos fatores de influência no jornalismo ainda é pouco pesquisada." (ESSER apud ZIPSER, 2002, p. 21, trad. nossa). Assim, a proposta de Esser vem estabelecer novos parâmetros para a análise cultural do fazer jornalístico.

Tendo em vista que o jornalismo é uma instituição que influencia a sociedade e é, ao mesmo tempo, formada por ela, temos que levar em conta que os valores culturais desta sociedade estarão imbricados no resultado desta atividade: o texto jornalístico, televisivo, impresso, radiofônico, online. É nesse aspecto que se pauta a pesquisa de Esser, segundo o próprio autor:

O ponto de partida dessa direção de pesquisa (e também deste trabalho) é o reconhecimento de que o jornalismo de cada país é marcado pelas condições emoldurais sociais gerais, por fundamentos históricos e jurídicos, limitações econômicas, bem como por padrões éticos e profissionais de seus agentes. (ESSER apud ZIPSER, 2002, p. 21, trad. nossa. Grifo nosso).

Como reitera Esser, são os elementos externos, definidos como condições sociais, fundamentos históricos e jurídicos e limitações econômicas, e os elementos internos, que abrangem os padrões éticos e profissionais dos agentes do fazer jornalístico, que definem o jornalismo exercido em cada país. Assim, o fazer jornalístico acontece de modo particular de acordo com a cultura em que se insere, e para o qual é feito. O jornalismo exercido no Brasil não poderá constituir-se do mesmo modo que a atividade jornalística em Portugal, por exemplo, visto que o contexto cultural para o qual as notícias são emolduradas e publicadas é diferente em cada país. 
Os fatores de influência mencionados por Esser vão desde a esfera social até a esfera subjetiva, passando pela esfera institucional e pela estrutura da mídia. A forma como organiza estes fatores é explicada pelo próprio autor no seguinte trecho:

Houve várias tentativas de identificar e classificar esses fatores de influência. Uma maneira simples de classificação desses fatores de influência é a 'metáfora da cebola'. Comparamos o jornalismo - retomando a ideia de Maxwell McCombs - com uma cebola, sendo que cada camada da cebola representa um fator de influência do fazer jornalístico. (ESSER apud ZIPSER, 2000, p. 21, trad. nossa).

Deste modo, Esser apresenta os elementos que julga influenciar o jornalismo em um gráfico (Fig. 1) constituído por quatro camadas no formato de uma cebola, que ele chama de modelo pluriestratificado integrado, no qual a camada externa abriga as camadas internas em um processo de inclusão e influência.

Figura 1 - Fatores de influência no jornalismo: modelo pluriestratificado integrado (ESSER - 1998)

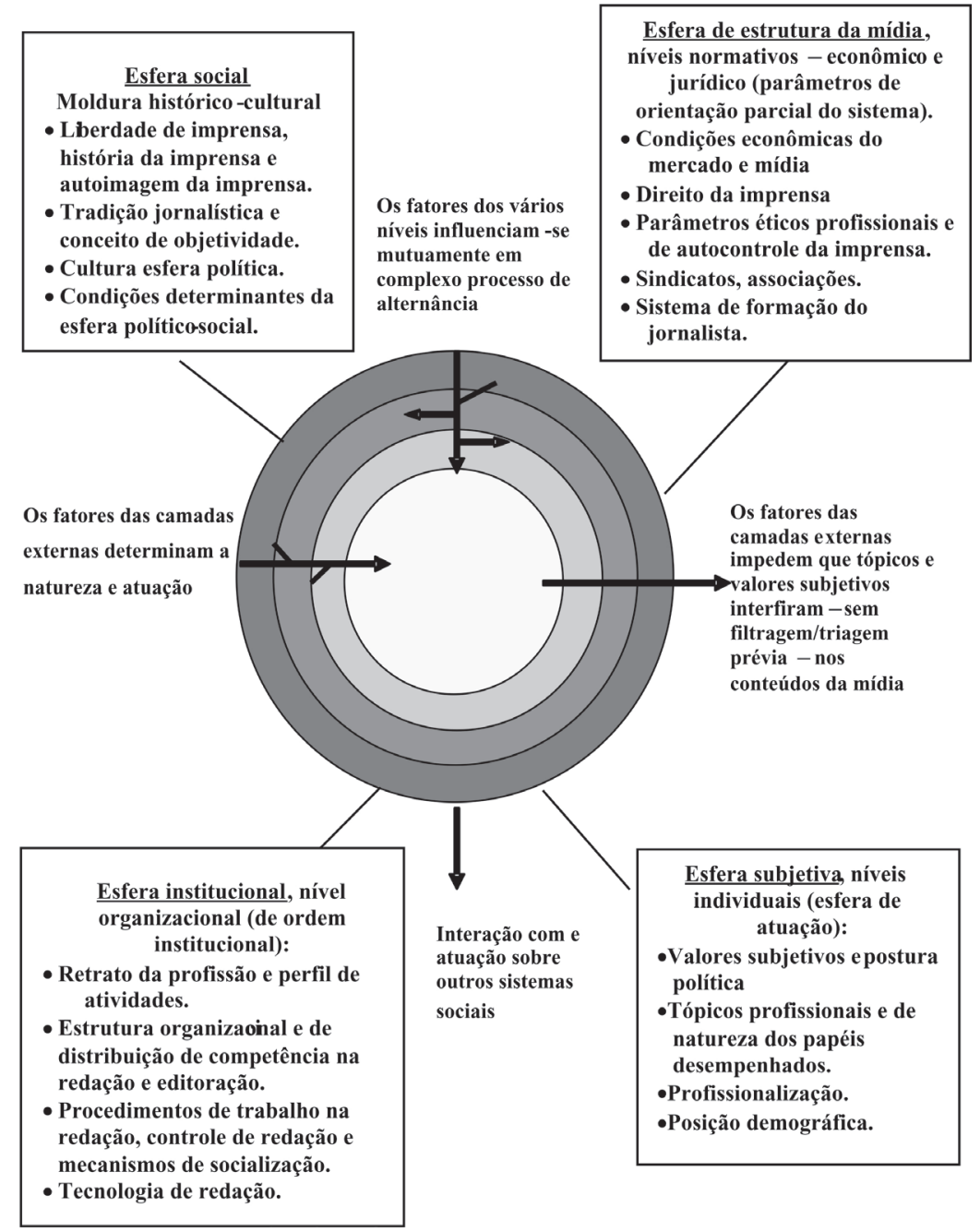


Na camada externa Esser apresenta a esfera social, definida por ele como moldura histórico-cultural. É nessa camada que se encontram os valores culturais da sociedade referentes à imprensa e ao próprio jornalismo, os valores e as condições determinantes da esfera político-social. Interior a esta camada encontra-se aquela destinada à esfera da estrutura da mídia, onde entram as condições econômicas e jurídicas da mídia, os valores éticos, os sindicatos, as associações e o sistema de formação do jornalista. Na esfera institucional, de nível organizacional, estão as estruturas do veículo, da redação e da editoração, os procedimentos de trabalho e as tecnologias de redação.

A camada interna é atribuída aos níveis individuais, na esfera subjetiva. São os fatores de formação individual, como os valores subjetivos e a postura política. Envolve também a profissionalização do jornalista e sua posição demográfica. Como podemos observar, as camadas apresentam-se em uma relação de interação e influência mútua entre si. Os fatores ganham força na medida em que atuam em conjunto, e não como elementos isolados. Isto é reiterado pelas palavras de Esser (apud ZIPSER, 2002, p. 26, trad nossa):

Os vários níveis encontram-se numa estreita relação de interação, influenciam-se reciprocamente, nenhum fator atua isoladamente, mas desenvolve sua influência somente em conjunto com as demais forças. As quatro esferas moldam o fazer jornalístico.

Ao mesmo tempo em que os elementos subjetivos não se manifestam sem que sejam filtrados pelas camadas posteriores, os elementos externos determinam a atuação do indivíduo, em nível subjetivo. Isto significa que o texto jornalístico é confeccionado com todos esses elementos alinhavados. De modo semelhante, e em analogia à proposta teórica de Nord mencionada no item anterior, a atividade tradutória também traz em si elementos externos e internos que se influenciam mutuamente e que formam o texto traduzido. As duas atividades são processos que acontecem em movimentos circulares, trazendo em si influência de seus elementos constitutivos e chegando ao leitor final, mas não terminando nele: por vezes faz-se necessário voltar às etapas iniciais do processo para rever os caminhos percorridos e os resultados alcançados.

Resultados de diversas filtragens, tanto o texto jornalístico quanto a tradução podem ser considerados prospectivos, já que visam atingir seus respectivos leitores. Como afirma Zipser (2002, p. 45-46): "Assim como na tradução, somente o destinatário - o leitor - fecha o círculo de produção e recepção do texto jornalístico.". Podemos considerar que o leitor, ao lado de todos os fatores que influenciam o fazer jornalístico, é peça importante na determinação das escolhas sobre o que vai ou não ser tratado 
em uma reportagem. Essas seleções é que determinam o enfoque dado pela reportagem sobre um fato. Nas palavras de Gomes (2000, p. 83): "A seleção feita deixa de lado não só acontecimentos, aos quais não se deu atenção [...], mas também os enfoques possíveis." Embora muitas vezes o enfoque priorizado por veículos da mídia não fiquem explícitos, o cotejo entre reportagens de diferentes meios pode nos indicar mais claramente o viés tomado por este ou aquele texto, ou seja, como se construíram as diferentes traduções de um fato.

\section{A interface tradução/jornalismo: possibilidade de diálogos}

Podemos observar diversas semelhanças nas cadeias formadoras das atividades jornalística e tradutória. Tendo como base, no campo da tradução, a proposta funcionalista de Christiane Nord, e a teoria de Frank Esser sobre os fatores de influência do fazer jornalístico, podemos constatar que existem elementos análogos que, como intencionamos mostrar, aproximam as duas atividades, tidas usualmente como distintas. Por excelência, a tradução traz como eixo principal o texto-fonte, sem o qual não teria razão de ser. Enquanto isso, o jornalismo acontece por haver, necessariamente, um fato sobre o qual noticiar. De um lado, temos fatores externos que interagem e se integram na formação tanto da atividade jornalística quanto tradutória; de outro, fatores internos que, filtrados pelos elementos externos, marcam os resultados das duas atividades. Por fim, temos o leitor, que completa o ciclo comunicativo, e que por esta razão influencia o direcionamento do texto final, fechando o ciclo formado na intercomunicação entre texto/fato e leitor.

Assim, podemos concluir que existem paralelos entre o fazer jornalístico e a tradução. Se, para existir, a tradução precisa partir de um texto-fonte, e o jornalismo necessita de um fato, podemos dizer que é semelhante a relação entre tradutores e jornalistas em relação às suas respectivas matérias-primas. Acrescentando o leitor nessa linha, o texto-fonte depende da tradução para que chegue a determinado público, do mesmo modo que o fato precisa ser noticiado para que alcance o leitor. Sendo assim, concordamos com a afirmação de Zipser (2002, p.45), segundo a qual "[...] podemos definir o trabalho da escritura do texto jornalístico como sendo uma 'tradução' prospectiva do fato noticioso, por excelência." Deste modo, o fazer jornalístico passa a ser tradução de fatos culturalmente representados na cultura de chegada, e não apenas transmissor direto e imparcial entre fato e leitor.

\section{Considerações finais}

Respeitando a proposta inicial deste artigo, chegamos ao final desta discussão mostrando a abrangência da tradução 
dos fatos no jornalismo, da mesma forma que a tradução de textos - as ideias - transita entre as línguas e culturas. Ambas as especialidades buscam trabalhar voltadas para seu leitor, usando de estratégias que passam a ser pertinentes para toda esta movimentação, seja no jornalismo ou na tradução. A adequação dos caminhos a serem escolhidos pelo jornalista, ou pelo tradutor, entram em confluência muito antes do que se imagina ou se pressupõe, quando em análises menos abrangentes. Partir da interface entre tradução e jornalismo acrescenta-nos novas possibilidades de entendimento das atividades tradutórias e jornalísticas. Aproxima profissionais, facilita caminhos de trabalho. Enriquece a prática e sensibiliza a discussão.

\begin{abstract}
This article aims to present the translational activity within the journalistic field, establishing the interface proposed by Zipser (2002) in which the journalist becomes a translator of facts, above all. Based, on the one hand, on Nord's functionalist proposal (1991) to contemplate the translation concept, and, on the other, on Esser's model (1998), which organizes the constitutive factors of journalism, we intend to show how a piece of news is prospectively constructed, i.e., from a source fact forward its reader.
\end{abstract}

Keywords: translation; journalism; cultural representation; nordian functionalism.

\title{
REFERÊNCIAS
}

BORNSTEIN, Juan Carlos Lago. El descubrimiento del otro. Una reflexión filosófica sobra la tradución y la interpretación. Madrid, 2001. Disponível em: http://www.filosofiaparaninos.org/Documentos/otros.htm. Acesso em: 25 mar 2011.

ESSER, Frank. Die Kraft hinter den Schlagzeilen: Englisher und deutscher Journalismus im Vergleich. München: Verlag Karl Albert GmgH Freiburg, 1998.

GOMES, Mayra Rodrigues. Jornalismo e ciências da linguagem. São Paulo: Edusp, 2000.

GONÇALVES, José Luiz Vila Real; MACHADO, Ingrid Trioni Nunes. Um panorama do ensino de tradução e a busca da competência do tradutor. In: Cadernos de Tradução, Florianópolis, Brasil. V. 1 n. 17, 2006. 
NORD, Christiane. Text analysis in translation: theory, methodology, and didactic application of a model for translation-oriented text analysis. Trad. Christiane Nord e Penelope Sparrow. Atlanta: Rodopi, 1991.

REISS, K.; VERMEER, H. J. Fundamentos para una teoría funcional de la traducción. Madri: Akal, 1996.

VERMEER, H.J. Esboço de uma teoria da tradução. Porto: Edições ASA, 1986.

ZIPSER, Meta Elisabeth. Do fato à reportagem: as diferenças de enfoque e a tradução como representação cultural. 2002. 274 f. Tese de Doutorado (Doutorado em Língua e Literatura Alemãs)-Universidade de São Paulo, 2002. Disponível em: <http://pget.ufsc.br/publicacoes/professores. php?autor=10>. Acesso em: 8 out 2010. 